\title{
Families and the Church: \\ From Objects of Pastoral Care to Sources of Spiritual Renewal
}

\author{
Thomas Knieps-Port le Roi
}

\begin{abstract}
The article explores the relationship between church and contemporary families from within the Roman Catholic tradition. This relationship is characterized by a growing alienation of families from the church on the one side and a magisterial position on the other side which seems rather unprepared, both in its theology and discipline, to face the increasing detraditionalization and diversification of today's family life. Although the more recent magisterium and in particular Pope John Paul II have revised previous teaching by depicting Christian families as agents of the Church's mission rather than as passive recipients of pastoral care and moral instruction, families still feel that the Church does not take them seriously, neither in their daily joys and sorrows nor in the genuine competences they bring into the Church. The author argues instead that families have a specific competence in faith practice and spirituality that is different, but also independent from, and therefore complementarity to the Church's traditional type of a predominantly monastic and celibate faith practice and spirituality. He refers for that purpose to K. Waaijman's threefold typology of spirituality in which family life is presented as the primary locus of a 'lay' spirituality that has to be distinguished from the theology, spirituality and religious practice of the official religious institution. The author concludes that the relationship between contemporary families and the Church will not improve unless the church community sees it as its major task to support, confirm, and encourage families in the responsibilities their members assume and the daily care they provide for each other.
\end{abstract}

Key words: Church, family, family ministry, lay spirituality, John Paul II

The reflections on the relationship between the Church and contemporary families in this paper originate from a specific, and therefore necessarily limited, context. My analysis starts from the present situation in most western European countries taking into account the impact of modernity on both the Church and the family in terms of secularization, individualization, pluralisation, and detraditionalization. Moreover, the following reflections are situated within my own Roman Catholic tradition and its theology and remain targeted towards it. It is beyond the scope of this paper to enter into a discussion with other cultural or societal backgrounds or different Christian traditions. I do hope, however, that by delineating my own particular theological position I provide some perspectives also for a cross-cultural and cross-denominational reflection and discussion on Christian families today.

\section{Brief Sketch of the Current Discrepancy between Church and Families and its Historical}

\section{Background}


In the context I come from there is today hardly any theological reflection or pastoral initiative with regard to the family that does not start from acknowledging a tremendous discrepancy between the reality of contemporary family life and the Church's discourse on the family. Although the Church has made a considerable effort over the past decades to highlight the family in its magisterial teaching, pastoral ministry, and theological reflection, it has finally not been very successful in overcoming the alienation of contemporary families from church life which, it seems, has only been growing since then. Whether religious belonging, mass attendance, domestic religious practice or transmission of faith to the next generation are concerned - it seems that the majority of families have terminated the former and long-standing coalition with the institutional church. ${ }^{1}$ The reason for this alienation is twofold and can be located on either side.

Just like other societal institutions, the family has undergone the aforementioned processes of pluralisation, individualization, and detraditionalization which have resulted in a broad diversity of family types and constellations. ${ }^{2}$ Consequently, the variety of living arrangements in which people today organize their blood and kin relations do no longer conform to the Church's monolithic and normative concept of the family, especially when it comes to lifelong marriage as its indispensable condition and foundation. But also the Church may be to blame for its difficult relationship with the family. As a matter of fact, the Latin Church throughout its history has not paid as much attention to the family as its more recent discourse suggests. Since the early times its attitude toward the family has been characterized by a theologically motivated relativisation for the sake of a better, i.e. celibate and childless, way of life on the one hand and its pragmatic acceptance on the other. ${ }^{3}$ Much

${ }^{1}$ See S. Klein, 'Kirche und Familie auf Distanz. Wie kann die Kirche eine Kirche der Familien sein', INTAMS review 16 (2010), pp. 164-173; M. N. Ebertz, 'Die “Koalition” von Familie und Kirche - Ein Auslaufmodel? Soziologische Perspektive', in B. Jans (ed.), Familienwissenschaftliche und familienpolitische Signale. Max Wingen zum 70. Geburtstag (Graftschaft: Vektor-Verlag, 2000), pp. 123-138.

${ }^{2}$ For a general overview see K. Kieran, 'Changing European Families: Trends and Issues', in J. Scott, J. Treas, and M. Richards (eds.), The Blackwell Companion to the Sociology of Families (Malden, MA: Blackwell, 2004), pp. 17-33; and N. F. Schneider, 'The Future of the Family in Europe: Diversity and Convergence', in H. Bertram and N. Ehlert (eds.), Family, Ties, and Care. Family Transformation in a Plural Modernity (Opladen etc.: Barbara Budrich Publishers, 2012), pp. 225-239.

${ }^{3}$ See P. Brown, The Body and Society. Men, Women, and Sexual Renunciation in Early Christianity (New York: Columbia University Press, 1988); H.-J. Klauck, 'Die Familie im Neuen Testament. Grenzen und Chancen', in G. Bachl (ed.), Familie leben. Herausforderungen für kirchliche Lehre 
as marriage and family life were seen as the second-best way of Christian discipleship, it could not be ignored that Christians, too, normally grow up in familial contexts which most of them intend to continue on their part. However, this was too thin a basis for according any particular theological weight to the family. In addition, down the ages the Roman Church has focused much more on marriage than on family relations, thus implementing a sophisticated juridical framework supported by theological speculations about its sacramental character and a normative sexual and conjugal morality. Precisely because the Catholic family doctrine has first and foremost been a teaching on marriage, contemporary theologians believe that what is wanting is a theology of the family that is not conceived as an 'extended marriage theology". Moreover, it has ultimately been this exclusive concentration on the marital relationship that has lead the Church in the more recent past to use the family merely as a bulwark against ideological attacks of diverse kinds on the core idea of marriage. While these attacks until very recently came from clearly identifiable ideologies that were hostile to the Church, the present erosion of central marital and family values emanates more silently and more steadily from within the families which leaves the Church much more vulnerable and helpless. It seems that the Church now has to pay a high price for its enduring negligence of a theology and ethics of the family. The complexity of the current societal transformations in the realm of family and living arrangements finds her largely unprepared to face the confrontation in an adequate way. ${ }^{5}$

und Praxis (Düsseldorf: Patmos, 1995), pp. 9-36; C. Osiek and D. L. Balch, Families in the New Testament World. Households and House Churches (Louisville, KY: Westminster/John Know Press, 1997).

${ }^{4}$ H. Halter, 'Kirche und Familie - einst und heute. Abriss der katholischen Familiendoktrin', in H. Halter, A. Ziegler and D. Mieth, Sexualität und Ehe. Der Christ vor einem Dauerproblem (Zürich: NZN Verlag, 1981).

${ }^{5}$ A number of theological publications across linguistic and denominational boundaries have in the meantime addressed and corrected this lack; see e.g. H.-G. Gruber, Familie und christliche Ethik (Darmstadt: WBG, 1995); D. S. Browning, B. J. Miller-McLemore and P. D. Couture, From Culture Wars to Common Ground. Religion and the American Family Debate (Louisville/KY: Westminster John Knox, 1997); C. Kissling, Familie am Ende? Ethik und Wirklichkeit einer Lebensform (Zürich: NZN, 1998); G. Marschütz, Familie humanökologisch. Theologisch-ethische Perspektiven (Münster: LIT, 2000); L. S. Cahill, Family. A Christian Social Perspective (Minneapolis, MN: University of Minnesota Press, 2000); F. C. Bourg, Where Two or Three Are Gathered. Christian Families as Domestic Churches (Notre Dame: University of Notre Dame Press, 2004); K. Ulrich-Eschemann, Lebensgestalt Familie - miteinander werden und leben. Eine phänomenologisch-theologisch-ethische Betrachtung (Münster: LIT, 2005); M. Ouellet, Divine 
This very brief analysis of the present situation would be incomplete if it did not include the tremendous efforts of the Roman magisterium, and in particular of the late Pope John Paul II, to put marriage and family issues on the ecclesial agenda and treat it with high priority. While this endeavour deserves respect and appreciation, I believe that it has not gone far enough to bring Church and contemporary families anyway closer to each other.

\section{Christian Family in Recent Magisterial Documents - a Missed Opportunity?}

Although late, the Roman Catholic Church seems to have understood the dramatic alienation of its discourse from contemporary family life. Drawing on the seminal considerations about marriage and the family in the Pastoral Constitution on the Church in the Modern World (Gaudium et spes) of the Second Vatican Council, ${ }^{6}$ Pope John Paul II in 1980 called together a Synod of Bishops to discuss the issues at stake and published what he considered the major outcome of the gathering in

Likeness. Toward a Trinitarian Anthropology of the Family (Grand Rapids: Eerdmans, 2006); A. Thatcher, Theology and Families (Malden, MA: Blackwell, 2007); B. Waters, The Family in Christian Social and Political Thought (Oxford: Oxford University Press, 2007); A. Dillen, Het gezin: à Dieu? Een contextuele benadering van gezinnen in ethisch, pedagogisch en pastoraaltheologisch perspectief (Brussel: Koninklijke Vlaamse academie van België voor wetenschappen en kunsten, 2009); J. H. Rubio, Family Ethics. Practices for Christians (Washington: Georgetown University Press, 2010); C. Rocchetta, Teologia della Famiglia. Fondamenti e prospettive (Bologna: Dehoniane, 2011).

${ }^{6}$ Pastoral Constitution on the Church in the Modern World Gaudium et Spes, nos. 48-52 (1965); http://www.vatican.va/archive/hist_councils/ii_vatican_council/documents/vatii_const_19651207_gaudium-et-spes_en.html; accessed 22-12-2012. 
the 1981 Apostolic Exhortation Familiaris consortio. ${ }^{7}$ Since then a multiplicity of further magisterial and dicasterial documents have appeared which all deal with the Christian family. ${ }^{8}$

If one compares Familiaris consortio with the previous teaching, one will notice a remarkable shift in the way the Church here talks about and addresses the family. From Leo XIII's encyclical Arcanum divinae in $1880^{9}$ over Pius XI's Casti connubii in $1930^{10}$ up to Vatican II the Church had always accorded marriage and the family a specific place in God's plan of creation and redemption and insisted that the hierarchy's main responsibility was to ensure that Christian families actually assume the position attributed to them by divine disposition. Thus, families were addressed at best as receivers of divine graces and objects of pastoral concern and for the rest were told what to do and how to behave in order to comply with the ecclesiastical expectations directed to them. These included mainly: bringing up the children in the Catholic faith, making them participate in the liturgical and sacramental life of the Church, taking care that sufficient priestly and religious vocations emerge out of the family, fostering a domestic life of prayer and charity, and following the Church's prescriptions in sexual and social morality. In this way the Church tried to use Christian families as a kind of outpost in an increasingly hostile world that had to ward off dangerous ideologies threatening to undermine the foundations of the Christian faith and of a society agreeable to God. ${ }^{11}$

\footnotetext{
${ }^{7}$ Pope John Paul II, Apostolic Exhortation Familiaris Consortio (1981) (henceforth referred to as FC); $\quad$ http://www.vatican.va/holy_father/john_paul_ii/apost_exhortations/documents/hf_jpii_exh_19811122_familiaris-consortio_en.html; accessed 22-12-2012. See also J. Grootaers and J.
} A. Selling, The 1980 Synod of Bishops on the Role of the Family. An Exposition of the Event and an Analysis of its Texts (Leuven: University Press, 1983).

${ }^{8}$ For an overview see Pontifical Council for the Family (ed.), Enchiridion on the Family. A Compendium of Church Teaching on Family and Life Issues from Vatican II to the Present (Boston: Pauline Books, 2004).

Pope Leo XIII, Encyclical Arcanum Divinae

(1880);

http://www.vatican.va/holy_father/leo_xiii/encyclicals/documents/hf_1-

xiii_enc_10021880_arcanum_en.html; accessed 22-12-2012.

10 Pope Pius Xn, Encyclical Connubii (1930); http://www.vatican.va/holy_father/pius_xi/encyclicals/documents/hf_p-xi_enc_31121930_casticonnubii_en.html; accessed 22-12-2012.

${ }^{11}$ See N. Mette, 'Die Familie in der kirchenamtlichen Verkündigung', Concilium(D) 31 (1995), pp. 330-345. 
The divine plan for marriage and the family provides the foundational theological framework also for John Paul II's approach in Familiaris consortio. But unlike his predecessors he does no longer address Christian families as passive followers of the hierarchy but rather as active agents in the salvific mission of the entire Church. From objects of pastoral concern and obedient receivers of ecclesiastical orders, families are supposed to be or become real subjects who together with all the other vocations in the Church share in the one and same mission of salvation for the world. Thus, John Paul II refers for instance to the family as being 'the object but above all the subject of pastoral care of the family' (FC 72). The Pope even dares to formulate that

the Christian family is grafted into the mystery of the Church to such a degree as to become a sharer, in its own way, in the saving mission proper to the Church: by virtue of the sacrament, Christian married couples and parents in their state and way of life have their own special gift among the People of God.' (LG 11) For this reason they not only receive the love of Christ and become a saved community, but they are also called upon to communicate Christ's love to their brethren, thus becoming a saving community. (FC 49, author's emphasis)

As is clear from this quote, this new vision is largely inspired by Vatican II's revised understanding of the Church as the "People of God" sharing in a common baptismal vocation as exposed in the Dogmatic Constitution on the Church, Lumen gentium. ${ }^{12}$ In this revised ecclesiology, the hierarchy of bishops and priests is secondary to and at the service of the common priesthood of all baptized rather than representing the top of a pyramidal structure of authority. From this perspective it is no longer the family that ought to be at the service of the Church, but rather a Church that puts itself "at the service of the family" in supporting, illuminating and assisting the families in their diverse situations. $^{13}$

12 Dogmatic Constitution on the Church Lumen Gentium

(1964); http://www.vatican.va/archive/hist_councils/ii_vatican_council/documents/vatii_const_19641121_lumen-gentium_en.html; accessed 22-12-2012.

${ }^{13}$ See Familiaris consortio, no. 1: 'Knowing that marriage and the family constitute one of the most precious of human values, the Church wishes to speak and offer her help to those who are already aware of the value of marriage and the family and seek to live it faithfully, to those who are uncertain and anxious and searching for the truth, and to those who are unjustly impeded from living freely their family lives. Supporting the first, illuminating the second and assisting the others, the Church offers her services to every person who wonders about the destiny of marriage and the family.' 
Likewise, the papal vision includes some powerful statements concerning Christian families as ecclesial communities hereby also referring to Vatican II and its retrieval of the notion of 'domestic church'. ${ }^{14}$ As is well known, Familiaris consortio calls the family 'a specific revelation and realization of ecclesial communion' (FC 21) and 'a living image and historical representation of the Church' (FC 49). If however one had hoped that the family were referred here to as a proper source of ecclesial communion that does not have to pass for that purpose through the cascade system of the hierarchical structures, one ends up in disappointment. The teaching of John Paul II in the end does not suggest the 'small church of the home' as a novum ecclesiale, as an ecclesial novelty that has no equivalent in the conventional church structures and could therefore be a gift - a critical gift more precisely - to the larger church. Instead, this teaching seems to be based upon and to further cement the view that the 'domestic sanctuary' of the family ${ }^{15}$ should be conceived of as a prolongation of the institutional church into its marginal edges, as a spelling out of ecclesial structures down to the smallest community, inviting families to model themselves on and subject themselves to the conventional practices of the Church in its teaching, liturgy, order and governance. $^{16}$

But not only for its ecclesial qualities, also with regard to an "authentic and profound conjugal and family spirituality" which the Pope calls for in Familiaris consortio, the Christian family is strongly reminded of the limitedness of its scope of action. In an allocution addressed to the Plenary Assembly of the newly created Pontifical Council for the Family in 1987, the Pope expresses his appreciation for the many initiatives in the field of marital and family spirituality but then admonishes these groups to strictly follow the doctrinal and practical guidelines of the magisterium. ${ }^{17}$ Nobody should of course deny that Christian families have to be faithful to the

\footnotetext{
${ }^{14}$ See Bourg, Where Two or Three Are Gathered; and T. Knieps-Port le Roi, G. Mannion and P. De Mey (eds.), The Household of God and Local Households. Revisiting the Domestic Church (Leuven: Peeters Publishers, 2013).

15 The term is used in the Second Vatican Council's Decree on the Apostolate of the Laity Apostolicam Actuositatem (1965), no. 11 ; http://www.vatican.va/archive/hist_councils/ii_vatican_council/documents/vatii_decree_19651118_apostolicam-actuositatem_en.html; accessed 22-11-2012.

${ }^{16}$ See T. Knieps-Port le Roi, 'The Domestic Church. Revisiting a Theological Concept at the Intersection of Family Studies and Ecclesiology', in Knieps, Mannion and De Mey, The Household of God, pp. 3-23.

17 'The promoters of marital and family spirituality have thus showed themselves to be full of initiative, but it is also well to stress their care for fidelity to the Church... The Church's
} 
Church, but what is problematic here is that the Church too hastily disposes of the proper and authentic input that families could bring to the faith life and practice. What I want to argue for in the remainder of this paper is precisely that families have a specific competence in faith practice and spirituality that is different, but also independent from, and therefore complementarity to the Church's traditional type of faith practice and spirituality which has been characterized as a celibate and monastic type. ${ }^{18}$ In order to retrieve this spiritual competence and potential, I will briefly analyse where the roots of its neglect are to be found. I have referred already to some theological motifs which have contributed to reducing marriage and family to a second-best way of Christian discipleship. Another factor to be considered here has to do with the social organization of religious life.

\section{Retrieving the "Lay Competence" of Families}

A major challenge many Christian Churches in the West have to face at present is a mentality in large parts of the population and even among their nominal members which has been described as 'believing without belonging' ${ }^{19}$. Regarding themselves as 'spiritual, but not religious', many contemporaries turn their back to the organized forms of religiosity in the institutional Christian churches and adhere to a sort of personal spirituality. ${ }^{20}$ While there is little doubt about the evidence as such, analysts of the religious landscape do not agree on how to explain it. Some see in it not more than the momentary flaring up of a subjective religiosity which fits into the irreversible

magisterium, which has clarified basic questions in recent years, must be followed faithfully in matters concerning the spouses' Christian formation or preparation for marriage." Pontifical Council for the Family (ed.), Enchiridion on the Family, p. 824.

${ }^{18}$ In recent publications the mainstream spiritual tradition in Catholicism has been characterized as deriving from and relying on celibate and monastic patterns which are increasingly difficult to adopt for people living in marital and family relations. See e.g. M. A. McPherson Oliver, Conjugal Spirituality (Kansas City, MO: Sheed \& Ward, 1994); see also T. Knieps-Port le Roi, 'Marital Spirituality: The Emergence of a New Paradigm in the Theology of Marriage and in Christian Spirituality', in T. Knieps-Port le Roi and M. Sandor (eds.), Companion to Marital Spirituality (Leuven: Peeters Publishers, 2008), pp. 15-44.

${ }^{19}$ G. Davie, Religion in Britain since 1945. Believing without Belonging (Oxford: Blackwell, 1994). ${ }^{20}$ See e.g. P. Heelas and L. Woodhead, The Spiritual Revolution. Why Religion is Giving Way to Spirituality (Oxford: Blackwell, 2005). 
process of secularization and confirms the decreasing relevance of religion in modern societies. ${ }^{21}$ Others, by contrast, find it hard to believe that religion has become obsolete and even detect signals of its renaissance since alternative forms of religious expression have ultimately freed themselves from the surveillance and control of traditional church-oriented religion. In this way, Thomas Luckmann had already in the 1960s pointed to the emergence of an 'invisible religion' beyond the visible religiosity within the established Christian Churches. ${ }^{22}$ However one may judge the diagnostic validity of this analysis which assumes a massive transformation in the field of religion rather than its decay, a particularly pertinent element in Luckmann's account is his description of the paradigmatic processes of institutional specialization and its consequences which religious traditions have undergone from primitive times up to their modern forms. ${ }^{23}$ In a nutshell, the theory implies that to the extent to which a small group of persons specialize in and dedicate themselves 'professionally' to religious matters, the majority of the believers in contrast find themselves in the position of religious 'illiterates' and thus of a religious 'laity'. While the former use their knowledge and expertise to homogenize the religious worldview into a uniform doctrine, develop an ecclesiastic organization, and demarcate the religious community from society at large, the latter are denied a direct access to religious truth and instead have to conform to the authoritative standards in terms of doctrinal beliefs, ritual practices, and ethical codes. According to Luckmann, such a segregation of roles and competences has reached in Christianity a degree that was not paralleled elsewhere. One may immediately think here of the sharp distinction between an ordained clergy and the common lay faithful which has been characteristic for Catholic Christianity until very recently. But such differentiation has not only been limited to the level of hierarchical structure and organizational power. Although less apparent and more subtle, a similar form of specialization has also occurred in the realms of spirituality and religious practices. Here as well we find a relatively small group of professional experts in the hermitages and monasteries or acting on their own behalf who have committed themselves to an extensive life of spirituality and religious practices which go beyond what the common faithful would be able or willing to engage in. Whether in ascetic exercises, contemplative concentration or ethical rigor, such 'virtuosos' provide

${ }^{21}$ See e.g. D. Voas and S. Bruce, 'The Spiritual Revolution: Another False Dawn for the Sacred', in K. Flanagan and P. C. Jupp (eds.), A Sociology of Spiritualityp (Aldershot: Ashgate, 2007), pp. 2342; see also S. Bruce, Secularization - In Defense of an Unfashionable Theory (Oxford: Oxford University Press, 2011).

${ }^{22}$ T. Luckmann, The Invisible Religion. The Problem of Religion in Modern Society (New York: Macmillan, 1967).

${ }^{23}$ See ibid., pp. 50-68. 
models of spiritual excellence which show in an exaggerated way what is expected from everyone but cannot realistically be done by everyone. ${ }^{24}$

There can be little doubt that institutional specialization has shaped Christianity to a great deal from within and, what is more, has also been constitutive for its shaping of western civilization and culture. One can hardly imagine what the Christian faith would have become without its official representatives who have casted it into a visible form and organizational structure. And the same is true for those who, off the tracks of political power and influence, have become virtuosos and experts in spiritual practices and have thus gained another sort of authority by providing orientation and direction for average Christians' devotional life. ${ }^{25}$ It seems, however, that this polar model with a relatively small religious elite on the one side and the mass of laypeople on the other is increasingly becoming dysfunctional in today's western societies. The risk that the official religious worldview drifts apart from the life-world of the laity and is no longer able to integrate their experiences into an overarching framework, has been identified by Luckmann as a general weakness of this form of religious socialization. ${ }^{26}$ If one adds to this the emancipative heritage of the Enlightenment which has also prompted Christians to question hierarchically structured forms of power and communal life, it becomes almost inevitable that the spiritual monopoly claimed by 'specialists' clashes with the modern mentality which grants the individual the capacity to think and act autonomously also in religious matters. ${ }^{27}$ In this situation every attempt from the side of the official church to containing the laity's move-out by insisting on conformity to the traditional distribution of tasks and competences, will have little prospect of success. What is even more problematic, however, is that in this way the Christian community cuts itself off from the religious

${ }^{24}$ For the concept of religious 'virtuosity' see B. Lang, 'Prophet, Priester, Virtuose', in H. G. Knippenberg and M. Riesebrodt (eds.), Max Webers 'Religionssystematik', (Tübingen: Mohr Siebeck, 2001), pp. 167-189; see also Idem, 'Persönliche Frömmigkeit. Ein Typus van Laienreligiosität in Geschichte und Gegenwart', in H. G. Knippenberg, J. Rüpke and K. Von Stuckrad (eds.), Europäische Religionsgeschichte: ein mehrfacher Pluralismus, vol. 2 (Göttingen: Vandenhoeck und Ruprecht, 2009), pp. 747-760.

${ }^{25}$ Scholars in religious studies show how vital the sometimes extreme religious practices of a few virtuosi have been in most religious traditions in that they reveal and maintain its intrinsic logic; see e.g. M. Riesebrodt, The Promise of Salvation. A Theory of Religion (Chicago: Chicago University Press, 2010), esp. pp. 122-148.

${ }^{26}$ Luckmann, Invisible Religion, pp. 77-106.

27 See I. Bocken, 'The Language of the Layman. The Meaning of the Imitatio Christi for a Theory of Spirituality', Studies in Spirituality 15 (2005), pp. 217-249, esp. pp. 217-220. 
experience and spiritual competence which also lay people possess and which specialization and expertise are supposed to support, shape, refine, even correct if necessary, but never to ignore or even deny. Seen from a purely sociological perspective, a church in which exclusively officials, theological experts, and spiritual virtuosos set the agenda, may be able to survive as long as the laity conform to this regime but is likely to collapse if they don't anymore. Theologically, however, such a setting does not deserve the name of Church which most ecclesiologies today define as a community of believers who as individuals are supposed to live in a personal relationship with God and to have a share in the community as a whole.

Hence, there are good reasons, both sociological and theological ones, to critically review the process and effects of institutional specialization along with the above mentioned pyramidal model of spirituality which raises the top performances of a few to the level of spiritual virtuosity while disqualifying the religious practices of the ordinary believers as average at best and inferior at the worst. In view of a dramatically changing religious landscape in late-modern societies both within and outside the church, the central question is whether the religious lay person is entitled to a genuine and authentic spirituality which is neither a lighter and thus inferior version of the virtuoso spirituality nor antagonistic to an officially approved type. Only if both components of the question can be answered positively, it can be made sure that both ordinary faithful may claim a fullyfledged Christian spirituality of their own and those outside or at the margins of the church are to be taken seriously in their spiritual search.

A promising path in that direction has been prepared by the Dutch scholar Kees Waaijman who, on the basis of a broad survey of concepts and practices in various religious traditions and beyond, has developed a typology of spirituality which offers an alternative to the pyramidal model described above. ${ }^{28}$ Waaijman distinguishes three major forms of spirituality which he classifies as the spirituality of the schools, the spirituality of counter-movements, and the spirituality of lay people. The first type, the spirituality of the schools, is that of the official and organized religion. The 'clergy' is its representative figure. Members of the clergy assume specific functions within and for the faith community and thus put themselves at the service of that community, be it the proximate religious community they live in, be it the broader social community they reach out to. Their practices can vary from introverted to more extraverted forms - they may lead a life of contemplation or devote themselves to the cult, they may provide instruction to others or take care of the sick, they may be involved in pastoral ministry or do missionary work; their primary concern though is always to organize the religious life and to build up religious community. It is not difficult to recognize in this type the spirituality of the monks, the religious, and the ordained ministers

${ }^{28}$ See K. Waaijman, Spirituality. Forms, Foundations, Methods (Leuven: Peeters, 2000). 
which has become so characteristic for Christianity. Very often this type of spirituality can be traced back to the source-experience by some founding figure who first attracts a small group of disciples and whose central message or insight has then to be transmitted to further generation of followers by means of rules and regulations which constantly have to be adapted to changing contexts. Waaijman calls this type 'school spirituality' since its primary focus is on pupils 'who are prepared to let the course of their life be transformed by the spiritual model offered by the school' ${ }^{29}$ It is here that spirituality can be learned professionally and brought to perfection and virtuosity.

The second type is that of counter-movements or spiritual dissidents. By way of illustration Waaijman refers to the prophets in the Old Testament who protest against the official religious practices at the King's court and the Jerusalem Temple or the desert fathers in the early church who withdraw from every form of human and religious community life. The list of spiritual dissidents includes flamboyant personalities like that of Jesus of Nazareth, Francis of Assisi or Dietrich Bonhoeffer and Oscar Romero in the more recent past. What is common to them is that they undergo at some moment in their lives an existential crisis which puts them at the margins of or even in opposition to the established order in the political or religious community they previously belonged to. Operating from outside the institutional patterns they challenge the narratives, concepts, and practices of the official religion and thus uncover precious sources of spirituality which can provide powerful, but often also short-term inspiration.

Next to these two well-known forms of spirituality Waaijman identifies a third type which he calls lay spirituality. This type has not left any rules or traditions passed down from generation to generation like the spiritual schools nor can it refer to any heroic or desperate acts like those of the religious dissenters. Lay spirituality exists in the unspectacular of everyday life and is situated in the realms of partner relations, family life, friendship, neighbourhood, and work space. Spiritual experiences in this field are 'primordial' experiences, i.e. experiences directly connected to fundamental life issues such as birth and death, upbringing and formation, home and work, commitment and care, etc. The narratives of the patriarchs in the Old Testament provide a good illustration for this specific type of personal relationship with God which is experienced 'at the time of birth and death, on the occasion of the naming and the weaning of the child, in the child's upbringing and at the time of marriage, upon entering new pasture grounds and leaving them, at the time of sickness and dangers, in the context of assemblies and mutual helpfulness ${ }^{, 30}$. Far away from the official religious practices of the King's court and the Temple in Jerusalem, these ordinary experiences are shared mainly within the family circle. They are passed on orally and therefore do

\footnotetext{
${ }^{29}$ Ibid., pp. 15.

${ }^{30}$ Ibid., pp. 20.
} 
not establish a tradition which materializes in treatises and libraries and is visualized in cathedrals and monasteries.

Waaijman's threefold typology is particularly interesting because it clearly recognizes that the religious laity occupy a genuine, authentic, and proper field of spirituality which can be characterized as primordial and is thus not dependent on nor derived from ecclesiastical organization, theological expertise, or spiritual excellence. Though present in all religious traditions, it has easily been overlooked or consciously been marginalized in traditions in which religious institutions have claimed the prerogative of defining what true religion and spirituality is. Equally important for our purposes is that Waaijman locates lay spirituality from the outset in the field of family life.

\section{Towards a New Relationship between Families and Church?}

The characteristic and distinctive features of a lay spirituality in the family context begin to emerge when contrasted with the other two types of Waaijman's typology, especially its institutional version. While the school spirituality is situated in the public sphere of the religious or broader

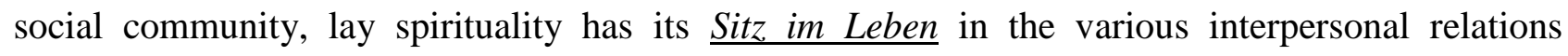
between partners, family members, friends, and neighbours. Consequently, lay or family spirituality originates from the personal life cycle whereas in the spirituality of the schools the focus is on transforming the individual course of life to make it fit into the spiritual paradigm of the school. Both types also differ in the way they deal with time and space. Time in family life is originally not structured by an official calendar mirroring the central events in the history of salvation; families celebrate birthdays, wedding days, anniversaries of death of family members, first days of schools, etc. because their primordial periodization is based on genealogy and inter-generational relations. Likewise, the original spatial dimension of family life is constituted by the natural habitat, the home and dwelling place, while institutional religion has churches, monasteries, or sanctuaries singled out as sacred spaces in which the divine can be encountered.

Contrasting the two types of spirituality in this way does not mean that families have to move out from the official places of worship nor that they ought to substitute the Christian calendar for their own biography and genealogy. But it makes them aware that the official narratives and practices of the church are secondary instances which should not conceal or overlay the primary or primordial experiences in which they may be addressed by God personally and directly. If the theological challenge included in this model of lay spirituality is understood, the major pastoral task will be to coach families in order to help them articulate the religious experiences connected with the family 
context they live in and subsequently make it shape their life styles and practices. I am afraid that the relationship between contemporary families and the church will not be improved unless the church community sees it as its major task to support, confirm, and encourage families in the responsibilities their members assume and the daily care they provide for each other. Many families live and witness in their own way to an evangelical life even if it does not fully look like it according to the 'official' standards.

\section{Personal Data.}

Thomas Knieps-Port le Roi, born in 1961, received his PhD in 1994 from the University of Bonn, Germany. He has been Senior Researcher at the International Academy for Marital Spirituality (INTAMS) in Brussels, Belgium, from 1995-2005. Since 2005 he is Associate Professor and holder of the INTAMS Chair for the Study of Marriage \& Spirituality at the Faculty of Theology and Religious Studies of the Catholic University Leuven in Belgium. He teaches courses in the fields of sexual, conjugal and family ethics and lay spirituality and is also the editor of the INTAMS review. Journal for the Study of Marriage and Spirituality. Among his recent book publications are Companion to Marital Spirituality, co-edited with M. Sandor (Leuven: Peeters, 2008) and The

Household of God and Local Households. Revisiting the Domestic Church, co-edited with G. Mannion and P. De Mey (Leuven: Peeters, 2013). 